\title{
PENGARUH KEPUASAN KERJA DAN KOMITMEN ORGANISASI TERHADAP KINERJA KARYAWAN PADA PT. POS LANGSA
}

\author{
Khairatun Hisan $^{1)^{*}}$, Zikriani ${ }^{1)}$, Abdul Hamid ${ }^{1)}$ \\ ${ }^{1)}$ Fakultas Ekonomi dan Bisnis Islam, IAIN Langsa \\ Penulis Korespondensi: *khairahisan@iainlangsa.ac.id, Zikriani@gmail.com, abdulhamid@iainlangsa.ac.id
}

\begin{abstract}
Abstrak
Penelitian ini bertujuan untuk mengetahui pengaruh kepuasan kerja dan komitmen organisasi terhadap kinerja karyawan pada PT. Pos Langsa. Sampel dalam penelitian ini berjumlah 23 orang. Metode analisis data yang digunakan yaitu analisis regresi linier berganda, uji t, uji $\mathrm{F}$, dan analisis koefisien determinasi. Persamaan regresi yang diperoleh dalam penelitian ini yaitu $\mathrm{Y}=3,125+0,512 \mathrm{X} 1+$ 0,166X2. Kepuasan kerja berpengaruh positif dan signifikan terhadap kinerja karyawan pada PT. Pos Langsa. Komitmen organisasi berpengaruh positif dan signifikan terhadap kinerja karyawan pada PT. Pos Langsa. Kepuasan kerja dan komitmen organisasi secara simultan berpengaruh signifikan terhadap kinerja karyawan pada PT. Pos Langsa. Kepuasan kerja dan komitmen organisasi mempengaruhi kinerja karyawan pada PT. Pos Langsa sebesar 62,5\%, sedangkan sisanya 37,5\% dipengaruhi oleh variabel lain di luar model penelitian ini.
\end{abstract}

Keywords: Kepuasan Kerja, Komitmen Organisasi, Kinerja

\section{Article Information:}

Received Date: 14 Juni 2021

Revised Date: 21 Juni 2021

Accepted Date: 7 Juli 2021 


\section{PENDAHULUAN}

Perusahaan merupakan suatu lembaga yang bertujuan untuk memperoleh keuntungan yang di dalamnya terdapat sumber daya manusia untuk menjalankan kegiatan operasional perusahaan. Tanpa sumber daya manusia maka perusahaan tidak akan berjalan. Oleh karena itu diperlukan sumber daya manusia yang handal dalam perusahaan agar tujuan-tujuan perusahaan dapat tercapai.

Setiap perusahaan akan selalu berusaha untuk meningkatkan kinerja pegawainya, dengan harapan apa yang menjadi tujuan perusahaan akan tercapai. Kinerja yang dicapai karyawan pada akhirnya akan memberikan kontribusi terhadap kinerja perusahaan. Beberapa faktor yang dianggap penting bagi peningkatan kinerja karyawan adalah kepuasan kerja dan komitmen organisasi (Kasmir, 2016).

Kepuasan kerja merupakan faktor yang dapat mempengaruhi kinerja karyawan. Kepuasan kerja berbeda-beda bagi setiap karyawan. Banyak faktor yang mempengaruhi kepuasan kerja karyawan, di antaranya adalah kesempatan untuk maju, gaji, kondisi kerja, aspek sosial dalam pekerjaan, dan komunikasi. Biasanya karyawan yang puas dengan apa yang diperolehnya dari perusahaan akan memberikan lebih dari apa diharapkan dan ia akan terus berusaha memperbaiki kinerjanya. Sebaliknya karyawan yang kepuasan kerjanya rendah, cenderung melihat pekerjaan sebagai hal yang menjemukan dan membosankan, sehingga ia bekerja dengan terpaksa, asalasalan dan dapat merugikan perusahaan.

Selain kepuasan kerja, komitmen organisasi juga dapat mempengaruhi kinerja karyawan. Komitmen organisasi merupakan sifat hubungan antara individu dengan organisasi kerja, dimana individu mempunyai keyakinan diri terhadap nilai-nilai dan tujuan organisasi kerja, adanya kerelaan untuk menggunakan usahanya secara sungguhsungguh demi kepentingan organisasi kerja serta mempunyai keinginan yang kuat untuk tetap menjadi bagian dari organisasi kerja.
Komitmen dapat juga berarti penerimaan yang kuat individu terhadap tujuan dan nilai-nilai organisasi (Hasibuan, 2013).

Saat ini perusahaan jasa pengiriman telah mengalami persaingan yang sangat ketat baik perusahaan swasta maupun perusahaan milik pemerintah. Tidak heran jika terkadang pelayanan perusahaan jasa pengiriman swasta saat ini telah banyak meningkatkan mutu pelayanan melalui sumber daya manusia yang mereka miliki. PT. Pos merupakan bagian dari BUMN (Badan Usaha Milik Negara) yang bergerak di bidang ekspedisi, distribusi suratsurat serta pengantar paket pos.

Permasalahan yang ada pada PT. Pos Langsa yaitu masih adanya karyawan dengan tingkat kepuasan kerja karyawan yang masih rendah. Padahal mereka menerima gaji yang layak dan sesuai harapan mereka. Kepuasan kerja yang rendah akan berdampak terhadap kinerja karyawan PT. Pos Langsa. Selain itu kepuasan kerja juga masih rendah yang salah satu penyebabnya adalah beban kerja serta tidak adanya kesempatan untuk mengembangkan karir di perusahaan.

Selain itu beberapa karyawan juga memiliki komitmen yang rendah terhadap perusahaan. Saat pertama bekerja di Kantor Pos Langsa, mereka berkomitmen untuk berkontribusi terhadap perusahaan. Namun setelah beberapa tahun bekerja ada beberapa karyawan yang tidak bersungguh-sungguh untuk berkontribusi terhadap perusahaan terutama dalam hal pekerjaan.

Banyak penelitian mengenai pengaruh dari kepuasan kerja dan komitmen organisasi terhadap kinerja telah dilakukan. Di antaranya oleh Sulianti (2009) dan Putrana (2016) yang menemukan bahwa kedua variabel independen berpengaruh signifikan terhadap variabel dependen. Sementara itu, Mekta (2017) mendapati bahwa hanya variabel kepuasan kerja yang berpengaruh positif dan signifikan terhadap kinerja. Oleh karena perbedaan temuan tersebut penulis ingin menguji kembali pengaruh kepuasan kerja dan komitmen 
organisasi terhadap kinerja karyawan PT. Pos Langsa.

\section{TINJAUAN PUSTAKA}

\section{Kepuasan Kerja dalam Organisasi}

Kepuasan kerja pada dasarnya merupakan sesuatu yang bersifat individual setiap individu memiliki tingkat kepuasan yang berbeda-beda sesuai dengan sistem nilai yang berlaku pada dirinya. Makin tinggi penilaian terhadap kegiatan dirasakan sesuai dengan keinginan individu, maka makin tinggi kepuasannya terhadap kegiatan tersebut (Cahyono, 2010). Kepuasan kerja mempengaruhi tingkat kedisiplinan karyawan, artinya jika kepuasan diperoleh dari pekerjaan, maka kedisiplinan karyawan baik. Sebaliknya jika kepuasan kerja kurang tercapai di pekerjaannya, maka kedisiplinan karyawan rendah (Tulus, 2008).

Kepuasan kerja adalah sikap emosional yang menyenangkan dan mencintai pekerjaannya. Sikap ini dicerminkan oleh moral kerja, kedisiplinan, dan prestasi kerja. Menurut Badriyah (2015), kepuasan kerja adalah sikap umum terhadap pekerjaan seseorang, selisih antara banyaknya ganjaran yang diterima seorang pekerja, dan banyaknya imbalan yang mereka yakini harus diterima. Menurut Sutrisno (2009), Kepuasan kerja adalah keadaan emosional yang menyenangkan atau tidak menyenangkan bagi para karyawan memandang pekerjaan mereka. Sedangkan Siagian (2015) mendefinisikan kepuasan kerja sebagai cara pandang seseorang baik yang bersifat positif maupun bersifat negatif tentang pekerjannya.

\section{Indikator Kepuasan Kerja}

Secara teoritis, faktor-faktor yang dapat mempengaruhi kepuasan kerja yaitu sebagai berikut (Siagian, 2015):

1. Kesempatan untuk maju

Dalam hal ini ada tidaknya kesempatan untuk memperoleh pengalaman dan peningkatan kemampuan selama kerja.

2. Keamanan kerja

Faktor ini disebut sebagai penunjang kepuasan kerja, baik bagi karyawan. Keadaan yang aman sangat mempengaruhi perasaan karyawan selama kerja.

3. Gaji
Gaji lebih sering menyebabkan ketidakpuasan, dan jarang orang mengekspresikan kepuasan kerjanya dengan sejumlah uang yang diperolehnya.

4. Perusahaan dan manajemen

Perusahaan dan manajemen yang baik adalah yang mampu memberikan situasi dan kondisi kerja yang stabil.

5. Pengawasan

Supervisi yang buruk dapat berakibat absensi dan turn over.

6. Faktor instrinsik dari pekerjaan

Atribut yang ada dalam pekerjaan mensyaratkan keterampilan tertentu. Sukar mudahnya serta kebanggaan akan tugas dapat meningkatkan atau mengurangi kepuasan.

7. Kondisi kerja

Termasuk di sini kondisi tempat, ventilasi, penyiaran, kantin, dan tempat parkir.

8. Aspek sosial dalam pekerjaan

Merupakan salah satu sikap yang sulit digambarkan tetapi dipandang sebagai faktor yang menunjang puas atau tidak puas dalam bekerja.

9. Komunikasi

Komunikasi yang lancar antar karyawan dengan pihak manajemen banyak dipakai alasan untuk menyukai jabatannya.

10. Fasilitas

Fasilitas rumah sakit, cuti, dana pensiun, atau perumahan merupakan standar suatu jabatan dan apabila dapat dipenuhi akan menimbulkan rasa puas.

Penelitian mengenai kepuasan kerja telah dilakukan oleh Sulianti (2009), Putrana (2016), dan Mekta (2017). Ketiganya mendapati bahwa kepuasan kerja berpengaruh positif signifikan terhadap kinerja karyawan. Oleh karena itu, hipotesis pertama dalam penelitian ini adalah kepuasan kerja berpengaruh positif dan signifikan terhadap kinerja.

\section{Komitmen Organisasi}

Komitmen organisasi didefinisikan sebagai derajat dimana karyawan terlibat dalam organisasinya dan berkeinginan untuk tetap menjadi anggotanya, dimana didalamnya mengandung sikap kesetiaan dan kesediaan karyawan untuk bekerja secara maksimal bagi organisasi tempat karyawan tersebut bekerja (Ivancevichm, 2007). 
Robbins dan Judge (2008mendefinisikan komitmen sebagai suatu keadaan dimana seorang individu memihak organisasi serta tujuan-tujuan dan keinginannya untuk mempertahankan keanggotaannya dalam organisasi. Komitmen organisasi menurut Rivai (2006) ialah suatu keadaan dimana seseorang karyawan memihak pada suatu organisasi tertentu dan tujuan-tujuannya, serta berniat memelihara keanggotaan dalam organisasi itu.

Dari beberapa pengertian komitmen organisasi di atas dapat disimpulkan bahwa komitmen organisasi adalah suatu sikap yang ditunjukkan oleh individu dengan adanya identifikasi, keterlibatan serta loyalitas terhadap organisasi.

\section{Indikator Komitmen Organisasi}

Menurut Rivai indikator komitmen organisasi dijelaskan sebagai berikut:

1. Identifikasi dengan organisasi yaitu penerimaan tujuan organisasi, dimana penerimaan ini merupakan dasar komitmen organisasi. Identifikasi karyawan tampak melalui sikap menyetujui kebijaksanaan organisasi, kesamaan nilai pribadi dan nilai-nilai organisasi, rasa kebanggaan menjadi bagian dari organisasi.

2. Keterlibatan yaitu adanya kesediaan untuk berusaha sungguh-sungguh pada organisasi. Keterlibatan sesuai peran dan tanggung jawab pekerjaan di organisasi tersebut. Karyawan yang memiliki komitmen tinggi akan menerima hampir semua tugas dan tanggung jawab pekerjaan yang diberikan padanya.

3. Loyalitas yaitu adanya keinginan yang kuat untuk menjaga keanggotaan di dalam organisasi. Loyalitas terhadap organisasi merupakan evaluasi terhadap komitmen, serta adanya ikatan emosional dan keterikatan antara organisasi dengan karyawan. Karyawan dengan komitmen tinggi merasakan adanya loyalitas dan rasa memiliki terhadap organisasi.

\section{Faktor-faktor yang Mempengaruhi Komitmen Organisasi}

Komitmen pegawai pada organisasi tidak terjadi begitu saja, tetapi melalui proses yang cukup panjang dan bertahap (Tjahjono, 2009). Sopiah (2008) mengemukakan ada empat faktor yang mempengaruhi komitmen karyawan. Berikut ini adalah keempat faktor tersebut.

1. Faktor personal, misalnya usia, jenis kelamin, tingkat pendidikan, pengalaman kerja dan kepribadian.

2. Karakteristik pekerjaan, misalnya lingkup jabatan, tantangan dalam pekerjaan, konflik peran, tingkat kesulitan dalam pekerjaan.

3. Karakteristik struktur, misalnya besar kecilnya organisasi, bentuk organisasi, kehadiran serikat pekerjan, dan tingkat pengendalian yang dilakukan organisasi terhadap karyawan.

4. Pengalaman kerja. Pengalaman kerja seorang karyawan sangat berpengaruh terhadap tingkat komitmen karyawan pada organisasi. Karyawan yang baru beberapa tahun bekerja dan karyawan yang sudah puluhan tahun bekerja dalam organisasi tentu memiliki tingkat komitmen yang berlainan.

Dari uraian di atas maka dapat dilihat bahwa faktor yang mempengaruhi komitmen organisasi yaitu faktor personal, karakteristik pekerjaan, karakateristik struktur dan pengalaman kerja.

Sulianti (2009) dan Putrana (2016) mendapati bahwa komitmen organisasi berpengaruh positif dan signifikan terhadap kinerja karyawan. Namun Mekta (2017) mendapati sebaliknya, bahwa komitmen organisasi berpengaruh negative terhadap kinerja organisasi. Oleh karena itu, hipotesis kedua dalam penelitian ini adalah komitmen organisasi berpengaruh positif dan signifikan terhadap kinerja.

\section{Pengertian Kinerja Karyawan dalam Organisasi}

Kasmir (2016) menyatakan bahwa kinerja adalah hasil kerja dan perilaku kerja seseorang dalam suatu periode, biasanya 1 tahun. Kemudian kinerja dapat diukur dari kemampuannya menyelesaikan tugas-tugas dan tanggung jawab yang diberikan. Artinya dalam bekerja mengandung unsur standar yang pencapaian harus dipenuhi, sehingga, bagi yang mencapai standar yang telah ditetapkan berarti berkinerja baik.

Kinerja adalah hasil yang diperoleh oleh suatu organisasi baik organisasi tersebut bersifat profit oriented dan non profit oriented 
(Fahmi, 20160. Menurut Yani (2012) kinerja adalah suatu hasil kerja yang dicapai seseorang dalam melaksanakan tugas-tugas yang dibebankan kepadanya yang didasarkan kecakapan, pengalaman dan kesungguhan serta waktu. Menurut Mangkunegara (2011), kinerja adalah hasil kerja secara kualitas dan kuantitas yang dicapai oleh seorang pegawai dalam melaksanakan tugasnya sesuai dengan tanggung jawab yang diberikan kepadanya.

Dari beberapa pendapat ahli di atas maka dapat disimpulkan bahwa kinerja adalah hasil kerja yang dicapai seseorang baik dari segi kualitas maupun kuantitas dengan standar yang telah ditetapkan.

\section{Indikator Kinerja}

Indikator penilaian kinerja menurut Kasmir (2016:208) yaitu sebagai berikut:

1. Kualitas (mutu)

Pengukuran kinerja dapat dilakukan dengan melihat kualitas (mutu) dari pekerjaan yang dihasilkan melalui suatu proses tertentu. Dengan kata lain bahwa kualitas merupakan suatu tingkatan dimana proses atau hasil dari penyelesaian suatu kegiatan mendekati titik sempurna.

2. Kuantitas

Untuk mengukur kinerja dapat pula dilakukan dengan melihat dari kuantitas yang dihasilkan seseorang. Dengan kata lain kuantitas merupakan produksi yang dihasilkan dapat ditunjukkan dalam bentuk satuan mata uang, jumlah unit, atau jumlah siklus kegiatan yang diselesaikan. Biasanya untuk pekerjaan tertentu sudah ditentukan kuantitas yang dicapai. Pencapaian kuantitas yang diharapkan adalah jumlah yang sesuai dengan target atau melebihi dari target yang telah ditetapkan.

3. Waktu (jangka waktu)

Untuk jenis pekerjaan tertentu diberikan batas waktu dalam menyelesaikan pekerjaannya. Artinya ada pekerjaan dengan batas waktu minimal dan batas waktu maksimal yang harus dipenuhi. Jika melanggar atau tidak memenuhi ketentuan waktu tersebut, maka dapat dianggap kinerjanya kurang baik, demikian pula sebaliknya. Dalam arti lebih luas ketepatan waktu merupakan kapan kegiatan tersebut dapat diselesaikan, atau suatu hasil produksi dapat dicapai dengan batas waktu yang telah ditetapkan sebelumnya. Untuk jenis pekerjaan tertentu makin cepat suatu pekerjaan, makin baik kinerjanya demikian pula sebaliknya makin lambat penyelesaian suatu pekerjaan, maka kinerjanya menjadi kurang baik.

4. Pengawasan

Pada dasarnya situasi dan kondisi selalu berubah dari keadaan yang baik menjadi tidak baik atau sebaliknya. Oleh karena itu, setiap aktivitas pekerjaan memerlukan pengawasan sehingga tidak melenceng dari yang telah ditetapkan. Dengan adanya pengawasan maka setiap pekerjaan akan menghasilkan kinerja yang baik.

5. Hubungan antar karyawan

Penilaian kinerja seringkali dikaitkan dengan kerjasama atau kerukunan antar karyawan dan antar pimpinan. Hubungan ini seringkali juga dikatakan sebagai hubungan antar perseorangan. Dalam hubungan ini diukur apakah seorang karyawan mampu untuk mengembangkan perasaan saling menghargai, serta dengan niat baik dan kerjasama antara karyawan yang satu dengan karyawan yang lain. Hubungan antar perseorangan akan menciptakan suasana yang nyaman dan kerjasama yang memungkinkan satu sama lain saling mendukung untuk menghasilkan aktivitas pekerjaan yang lebih baik. Hubungan antar karyawan ini merupakan perilaku kerja yang dihasilkan seorang karyawan.

\section{METODE PENELITIAN}

Jenis penelitian yang digunakan adalah dengan menggunakan metode kuantitatif. Metode kuantitatif adalah metode yang digunakan untuk penyajian pada penelitian dalam bentuk angka-angka atau statistik.

Analisis regresi linier berganda digunakan untuk mengukur pengaruh antara lebih dari satu variabel bebas terhadap variabel terikat. Rumus analisis regresi linier berganda yaitu:

$\mathrm{Y}=\mathrm{a}+\mathrm{b}_{1} \mathrm{X}_{1}+\mathrm{b}_{2} \mathrm{X}_{2}+\mathrm{e}$

Dimana:

$\mathrm{Y} \quad=$ Kinerja Karyawan

$\mathrm{X}_{1} \quad=$ Kepuasan Kerja

$\mathrm{X}_{2} \quad=$ Komitmen Organisasi 


$$
\begin{aligned}
& \text { a }=\text { Konstanta } \\
& \mathrm{b}_{1}, \mathrm{~b}_{2}=\text { Koefisien regresi } \\
& \mathrm{e}=\text { Error }
\end{aligned}
$$

HASIL DAN PEMBAHASAN

Uji Analisis Regresi Linier Berganda

Tabel 1 Hasil Uji Linear Berganda

\begin{tabular}{|l|r|r|r|r|r|}
\hline \multirow{2}{*}{ Model } & \multicolumn{2}{|c|}{$\begin{array}{c}\text { Unstdzd. } \\
\text { Coefficients }\end{array}$} & $\begin{array}{c}\text { Stdizd } \\
\text { Coeffici } \\
\text { ents }\end{array}$ & & \multirow{2}{*}{. } \\
\cline { 2 - 4 } & \multicolumn{1}{|c|}{$\mathrm{B}$} & \multicolumn{1}{c|}{$\begin{array}{c}\text { Std. } \\
\text { Error }\end{array}$} & \multicolumn{1}{c|}{ Beta } & \multicolumn{1}{c|}{$\mathrm{t}$} & Sig. \\
\hline 1 (Constant) & 3.125 & .327 & & 2.586 & .013 \\
X1 & .512 & .084 & .422 & 2.348 & .004 \\
X2 & .166 & .672 & .508 & 2.132 & .016 \\
\hline
\end{tabular}

Berdasarkan tabel di atas dapat dirumuskan model regresi linier berganda yaitu sebagai berikut.

$$
Y=3,125+0,512 X_{1}+0,166 X_{2} \text {. }
$$

Persamaan ini dapat dijelaskan sebagai berikut:

1. Konstanta sebesar 3,125 menunjukkan nilai positif, yang berarti bahwa apabila kepuasan kerja dan komitmen organisasi bernilai nol maka kinerja sebesar 3,125.

2. Nilai koefisien regresi variabel kepuasan kerja bernilai 0,512 dan bertanda positif. Artinya, apabila kepuasan kerja meningkat satu satuan maka kinerja akan meningkat sebesar 0,512 satuan dengan asumsi variabel komitmen organisasi tetap (tidak berubah).

3. Nilai koefisien regresi variabel komitmen organisasi bernilai 0,166 dan bertanda positif. Artinya, apabila komitmen organisasi meningkat satu satuan maka kinerja akan meningkat sebesar 0,166 satuan dengan asumsi variabel kepuasan kerja tetap (tidak berubah).

\section{Uji Model $\mathbf{R}^{2}$ (Koefisien Determinasi)}

Dari analisis data diketahui nilai nilai $\mathrm{R}$ Square sebesar 0,625. Artinya, kepuasan kerja dan komitmen organisasi mempengaruhi kinerja karyawan pada PT. Pos Langsa sebesar $62,5 \%$, sedangkan sisanya $37,5 \%$ dipengaruhi oleh variabel lain di luar model penelitian ini.

\section{Uji t (Parsial)}

Uji t digunakan untuk menguji apakah secara individu variabel bebas berpengaruh secara signifikan terhadap variabel terikat.

1. Pengaruh Kepuasan Kerja terhadap

Kinerja Karyawan

Dari hasil uji $t$ dapat dilihat nilai $t$ sig. sebesar 0,004 . Oleh karena nilai t sig. < $0,05(0,004<0,05)$ maka dapat dinyatakan bahwa kepuasan kerja berpengaruh positif dan signifikan terhadap kinerja. Artinya hipotesis $\mathrm{H}_{1}$ diterima.

2. Pengaruh Komitmen Organisasi terhadap Kinerja Karyawan

Dari hasil uji $\mathrm{t}$ dapat dilihat nilai $\mathrm{t}$ sig. sebesar 0,016 . Oleh karena nilai t sig. < $0,05(0,016<0,05)$ maka dapat dinyatakan bahwa komitmen organisasi berpengaruh positif dan signifikan terhadap kinerja. Artinya hipotesis $\mathrm{H}_{2}$ diterima.

\section{Uji F (Simultan)}

Uji F digunakan untuk menguji apakah secara simultan variabel bebas berpengaruh secara signifikan terhadap variabel terikat.

F sig. Sebesar 0,014. Oleh karena nilai F sig. < $0,05(0,014<0,05)$ maka dapat dinyatakan bahwa kepuasan kerja dan komitmen organisasi secara simultan berpengaruh positif dan signifikan terhadap kinerja karyawan. Artinya hipotesis $\mathrm{H}_{3}$ diterima. Hasil penilitian ini sejalan dengan penelitian oleh Sulianti (2009), Putrana (2016), dan Mekta (2017) yang mendapati bahwa kepuasan kerja dan komitmen organisasi berpengaruh signifikan terhadap kinerja karyawan.

\section{KESIMPULAN DAN SARAN}

Berdasarkan hasil analisis data dan pembahasan maka dapat ditarik kesimpulan bahwa kepuasan kerja berpengaruh positif dan signifikan terhadap kinerja karyawan pada PT. Pos Langsa dengan nilai koefisien regresi sebesar 0,512. Artinya, apabila kepuasan kerja meningkat satu satuan maka kinerja akan meningkat sebesar 0,512 satuan. Demikian pula, komitmen organisasi berpengaruh positif dan signifikan terhadap kinerja karyawan pada PT. Pos Langsa dengan nilai koefisien regresi sebesar 0,166. Artinya, apabila komitmen organisasi meningkat satu satuan maka kinerja 
akan meningkat sebesar 0,166 satuan. Secara simultan, kepuasan kerja dan komitmen organisasi juga berpengaruh signifikan terhadap kinerja karyawan pada PT. Pos Langsa.

Adapun saran untuk penelitian selanjutnya agar dapat menambah beberapa variabel independen dan memperbsar jumlah sampel agar penelitiannya menjadi lebih representative lagi.

\section{REFERENSI}

Badriyah, Mila, 2015, Manajemen Sumber Daya Manusia. Bandung: Pustaka Setia.

Fahmi, Irham, 2016, Manajemen Sumber Daya Manusia (Teori dan Aplikasi). Bandung: Alfabeta.

Ghozali, Imam, 2011, Aplikasi Analisis Multivariate Dengan Program SPSS, Semarang: Badan Penerbit Universitas Diponegoro.

Hasibuan, Malayu SP, 2013. Manajemen Sumber daya Manusia, Jakarta: Bumi Aksara.

Ivancevich, John, 2007, Perilaku dan Manajemen Organisasi, Jakarta: Erlangga.

John Suprihanto, 2005, Manajemen Personalia, Yogyakarta: BPFE.

Kasmir, 2016, Manajemen Sumber Daya Manusia : Teori dan Praktik, Jakarta: Rajawali Pers.

Mangkunegara, Anwar Prabu, 2011, Sumber Daya Manusia Perusahaan, Bandung: Remaja Rosdakarya.

Martoyo, Susilo, 2007, Manajemen Sumber Daya Manusia, Yogyakarta: BPFE.

Mekta, Hendrawan Qonit, Pengaruh Kepuasan Kerja dan Komitmen Organisasi terhadap Kinerja Karyawan PT. Indra Kelana Yogyakarta, Jurnal Ilmiah, 2017, Vol 2.

Putrana, 2016, Pengaruh Kepuasan Kerja dan Komitmen Organisasi terhadap Kinerja Karyawan pada PT. Gelora Persada Mediatama Semarang. Jurnal Ilmu Manajemen, Vol 1, Hal 1-15.

Rivai, Veithzal, 2006, Manajemen Sumber Daya Manusia untuk Perusahaan, Jakarta: Raja Grafindo Persada.

Robbins SP dan Judge, 2008, Perilaku Organisasi, Jakarta: Salemba Empat.
Siagian, Sondang P, 2015, Manajemen Sumber Daya Manusia, Jakarta: Bumi Aksara.

Sopiah, 2008, Perilaku Organisasi, Jakarta: Yogyakarta: Andi.

Sulianti, 2009, Pengaruh Komitmen Organisasional dan Kepuasan Kerja terhadap Kinerja Karyawan PT. Perkebunan Nusantara III di Sumatera Utara, Jurnal Manajemen, Vol 1, Hal 18.

Sutrisno, Edy, 2009, Manajemen Sumber Daya Manusia, Jakarta: Prenadamedia Group.

Tjahjono, Heru Kurnianto, 2009, Manajemen Sumber Daya Manusia, Yogyakarta: Visi Solusi Madani.

Tri Cahyono, Bambang, 2010, Manajemen Sumberdaya Manusia, Jakarta: Badan Penerbit IPWI.

Tulus, Agus, 2008, Manajemen Sumber Daya Manusia, Jakarta: Gramedia Pustaka Utama. 